Supporting Information

\title{
Tannic acid as a small-molecule binder for silicon
}

\section{anodes}

Kasturi T. Sarang, ${ }^{a}$ Xiaoyi Li ${ }^{b}$ Andrea Miranda, ${ }^{c}$ Tanguy Terlier, ${ }^{d}$ Eun-Suok Oh, ${ }^{* e}$ Rafael

Verduzco, ${ }^{* b, f}$ Jodie L. Lutkenhaus*a,g

a Artie McFerrin Department of Chemical Engineering, Texas A\&M University, College

Station, Texas 77843, United States

b Department of Chemical and Biomolecular Engineering, Rice University, Houston, Texas

77005, United States

c Department of Chemistry, Rice University, Houston, Texas 77005, United States

d SIMS Lab, Shared Equipment Authority, Rice University, Houston, TX 77005, United States

e School of Chemical Engineering, University of Ulsan, Ulsan 44611, South Korea

${ }^{\mathrm{f}}$ Department of Materials Science and NanoEngineering, Rice University, Houston, Texas

77005, United States

g Department of Materials Science and Engineering, Texas A\&M University, College Station, United States

Corresponding author email: jodie.lutkenhaus@tamu.edu, rafaelv@ rice.edu, eunsuokoh@gmail.com 


\section{Materials Characterization}

X-ray photoelectron spectroscopy (XPS) was performed using Omicron ESCA Probe (Omicron Nanotechnology) with a monochromated $\mathrm{Mg}$ Ka radiation $(\mathrm{hm}=1253.6 \mathrm{eV})$. XPS survey scans were performed with an analyzer pass energy of 100-1100 eV (1.0 eV steps, $50 \mathrm{~ms}$ dwell time), while high resolution scans of carbon (C 1s) and silicon (Si 2p) were performed with a pass energy of $150 \mathrm{eV}(0.05 \mathrm{eV}$ steps, $200 \mathrm{~ms}$ dwell time). All spectra were calibrated with the $\mathrm{C} 1 \mathrm{~s}$ photoemission peak for $\mathrm{sp}^{2}$-hybridized carbons at $284.5 \mathrm{eV}$ and the full width half minimum (FWHM) was constrained. Curve fitting of C 1s and Si 2p spectra was conducted using a GaussianLorentzian peak shape after Shirley-type background correction.

For scanning electron microscopy (SEM) combined with energy dispersive X-ray spectroscopy (EDS) analysis, the samples before cycling were dried in vacuum oven at room temperature for 24 $\mathrm{h}$ before analysis; and the samples after cycling were washed with dichloromethane to remove excess lithium salt. They were then dried inside the glovebox for two days followed by drying in vacuum oven at room temperature for one day. SEM with EDS experiment was performed using JEOL JSM-7500F. The acceleration voltage was set to $20 \mathrm{kV}$ and the working distance was set to $15 \mathrm{~mm}$. The data acquisition and data processing for EDS was done using INCA software. For the microscope setup, the probe current and process time were optimized to obtain a deadtime of approximately $45 \%$. For quant optimization, the measurements were done on a reference copper tape which was placed besides the sample on sample holder. Different homogenous rectangular areas on the samples were selected to acquire the data. All these steps were done to ensure that process parameters were optimized to get a good quantification of elements present in the sample. 


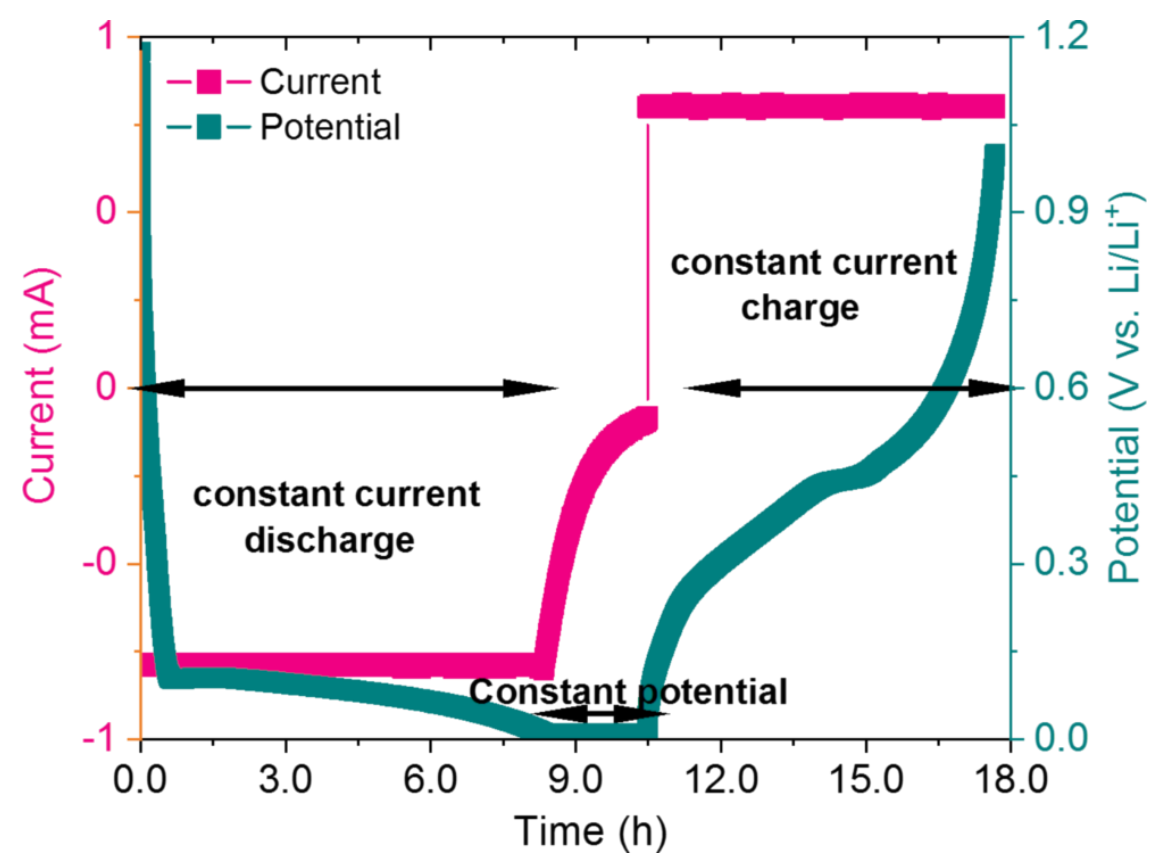

Figure S1. Plot of current and potential vs. time to demonstrate the constant current-constant voltage (CC-CV) mode. All galvanostatic cycling experiments were performed with the first 5 cycles at $0.1 \mathrm{C}$ in $\mathrm{CC}-\mathrm{CV}$ mode and the remaining cycles at $0.5 \mathrm{C}$ in constant current $(\mathrm{CC})$ mode. In CC mode, a discharge current was applied until the potential dropped from open circuit potential (OCP) to $0.01 \mathrm{~V}$. During this step, $\mathrm{Li}^{+}$ions move from the Li metal to the silicon anode. In the next step (i.e. CV step), the potential was held at $0.01 \mathrm{~V}$ until the current reached a very low value (here, we used the value of current that we calculated at $0.01 \mathrm{C}$ ). This step provides enough time for lithiation to ensure that the entire capacity of the silicon anode is utilized. In the final step, a charge current is applied and $\mathrm{Li}^{+}$ions move back to Li metal from the silicon anode until the potential reaches $1 \mathrm{~V}$. 
(a)

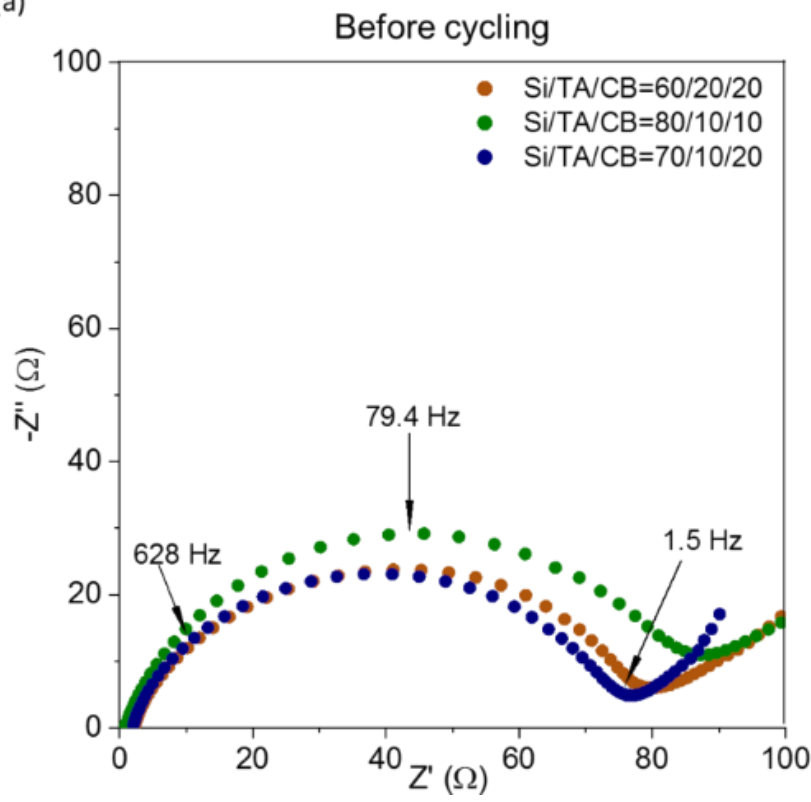

(b)

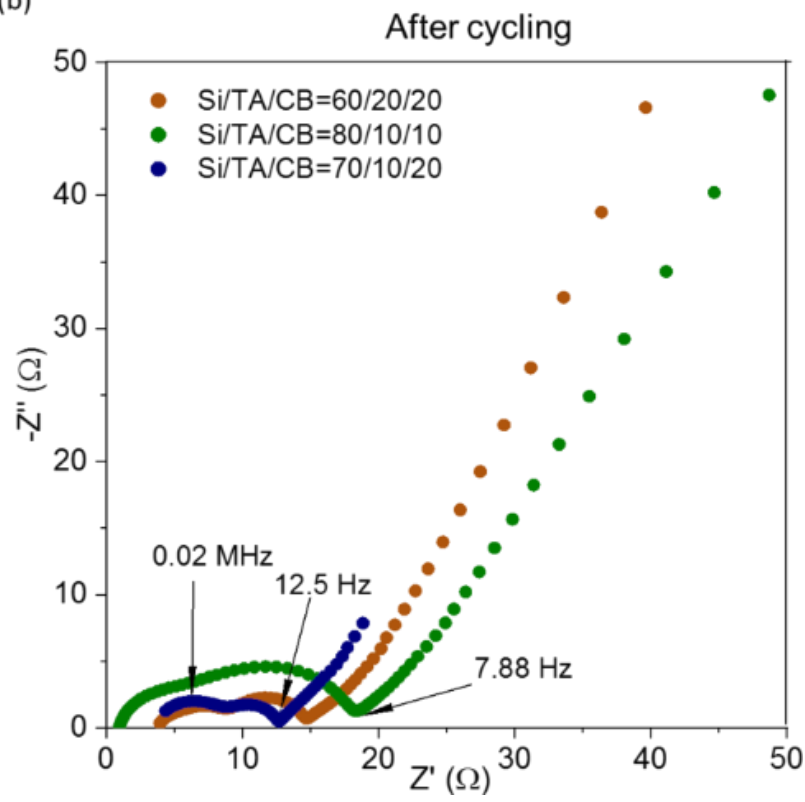

Figure S2. Nyquist plot of Si/TA/CB electrodes with different compositions (a) before and (b) after 50 cycles. Electrochemical impedance spectroscopy (EIS) was performed on fresh and cycled electrodes at a potential of $0.2 \mathrm{~V}$. The AC amplitude was $10 \mathrm{mV}$. The frequency range was 100 $\mathrm{kHz}$ to $5 \mathrm{mHz}$. 

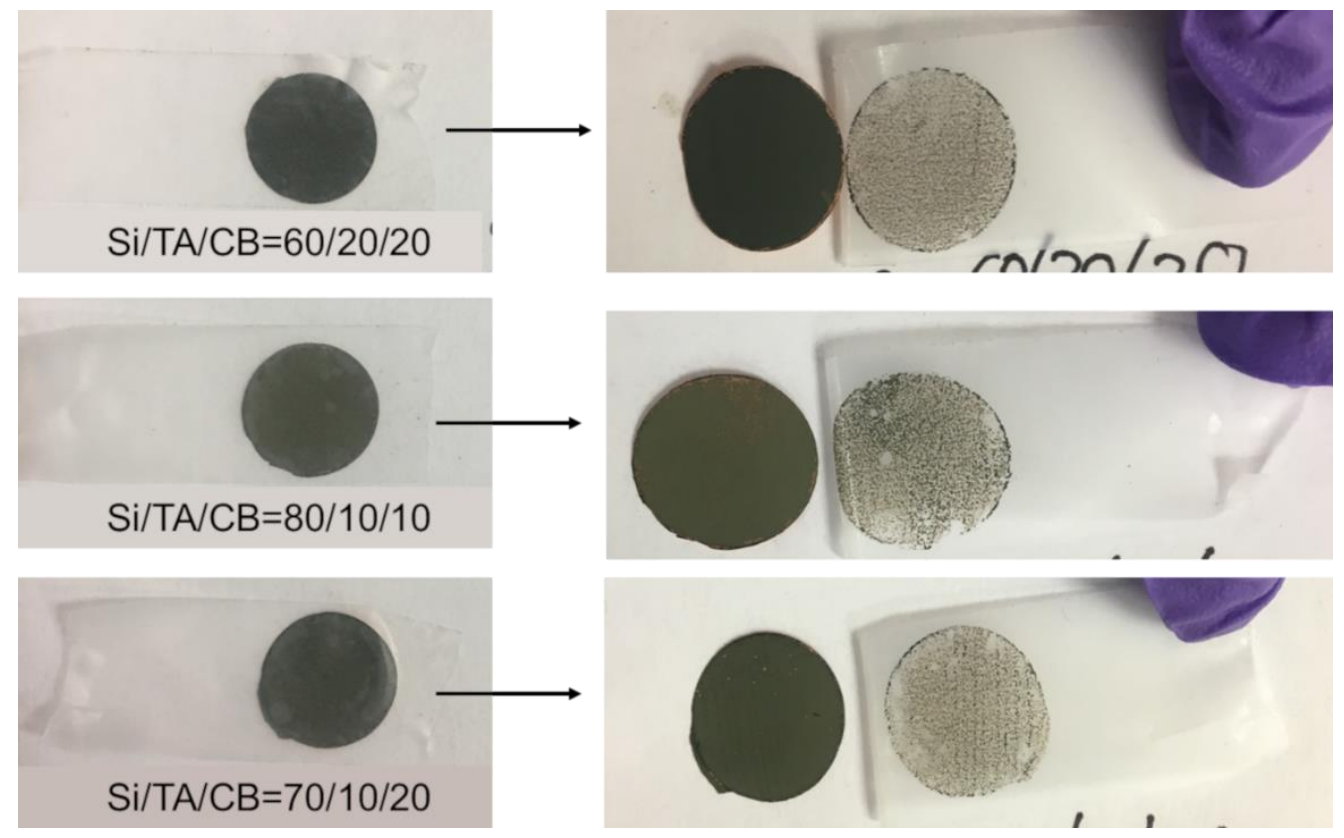

Figure S3. Peel test of $\mathrm{Si} / \mathrm{TA} / \mathrm{CB}=60 / 20 / 20, \mathrm{Si} / \mathrm{TA} / \mathrm{CB}=80 / 20 / 20$, and $\mathrm{Si} / \mathrm{TA} / \mathrm{CB}=70 / 10 / 20$ electrodes. A $3 \mathrm{M}$ tape was used here, and it was pressed on the samples for 5 seconds with equal force before peeling it off.

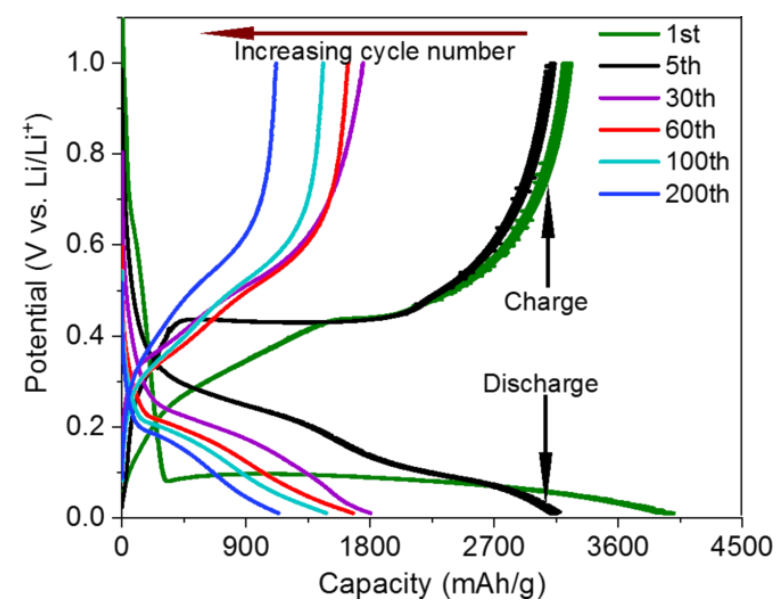

Figure S4. Voltage profile of $\mathrm{Si} / \mathrm{TA} / \mathrm{CB}=70 / 10 / 20$ electrode for different cycle numbers. 


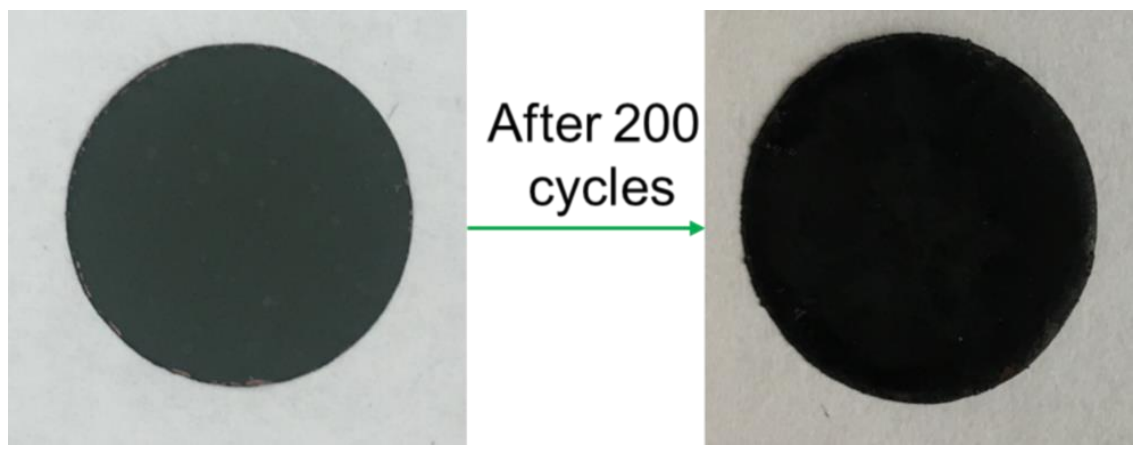

Figure S5. Picture of $\mathrm{Si} / \mathrm{TA} / \mathrm{CB}=70 / 10 / 20$ electrode before and after galvanostatic cycling for 200 cycles. The picture for the cycled electrode was taken after it was washed with dichloromethane and dried inside the glovebox.

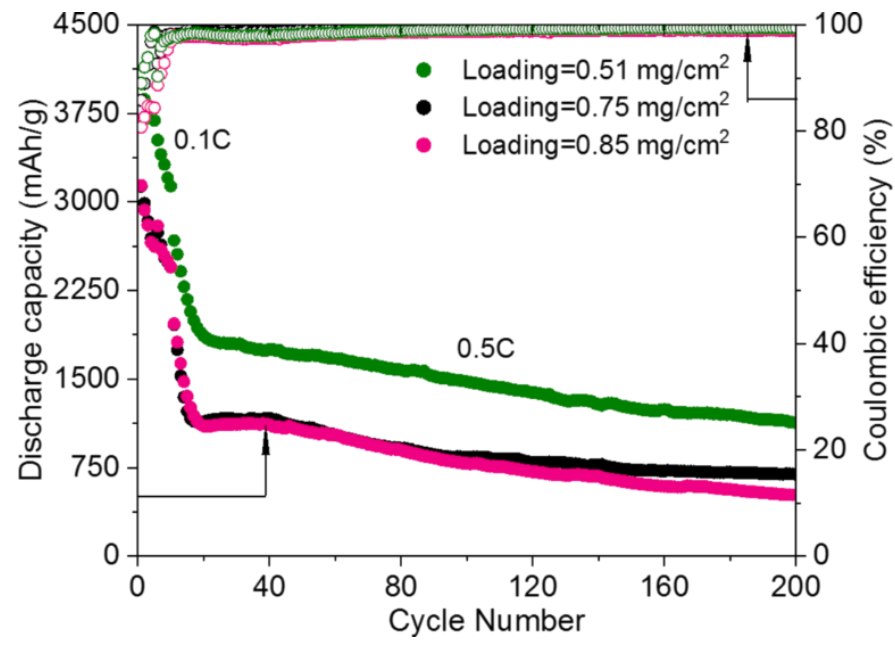

Figure S6. Galvanostatic cycling of $\mathrm{Si} / \mathrm{TA} / \mathrm{CB}=70 / 10 / 20$ electrodes for different active material loadings. Galvanostatic cycling was performed at $0.1 \mathrm{C}$ in $\mathrm{CC}-\mathrm{CV}$ mode for the first 5 cycles and at $0.5 \mathrm{C}$ in $\mathrm{CC}$ mode for the remaining cycles. 


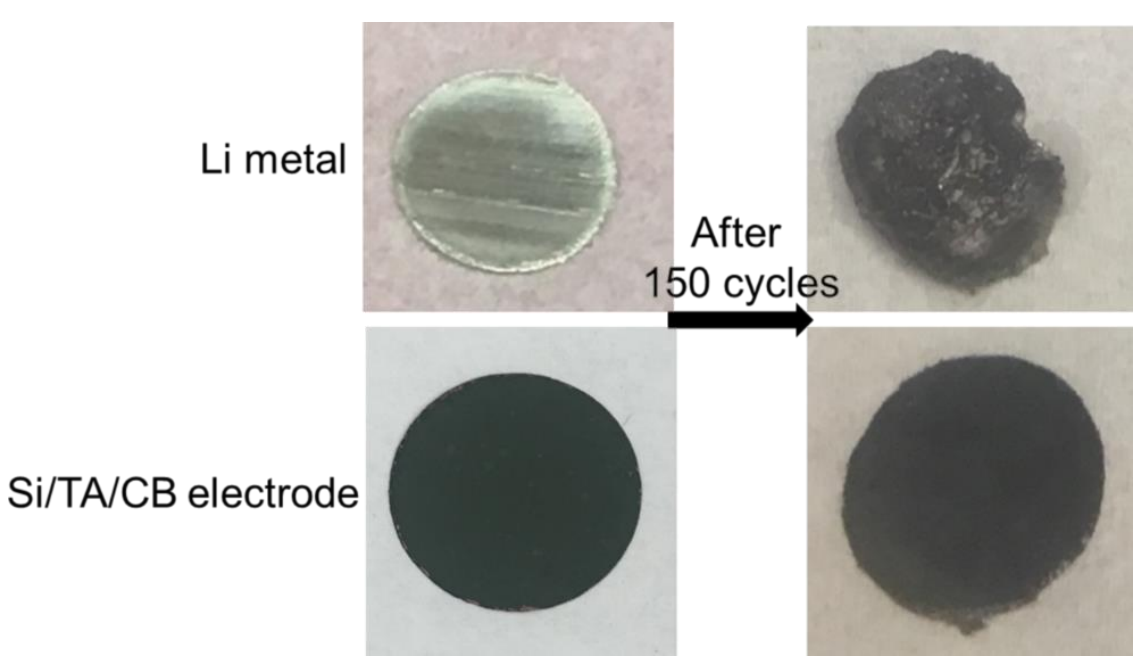

Figure S7. Photographs of lithium metal counter electrodes and Si/TA/CB=70/10/20 electrodes (a) before and (b) after 150 cycles. The lithium metal had turned black, which implies it became the limiting factor during cycling. 
Table S1. Comparison of different silicon anode binders.

\begin{tabular}{|c|c|c|c|c|c|}
\hline Binder & $\begin{array}{l}\text { Si/binder/CB } \\
\text { (by mass) }\end{array}$ & $\begin{array}{l}\text { Si } \\
\text { Loading } \\
\left(\mathrm{mg} / \mathrm{cm}^{2}\right)\end{array}$ & $\begin{array}{l}\text { Electrolyte } \\
\text { (Salt, Solvent, } \\
\text { Additive) }\end{array}$ & $\begin{array}{l}\text { Cycling } \\
\text { Performance }\end{array}$ & Ref \\
\hline \multicolumn{6}{|c|}{ Water soluble binders } \\
\hline \multirow{2}{*}{ Tannic acid } & \multirow{2}{*}{$70 / 10 / 20$} & $0.75-0.82$ & \multirow{2}{*}{$\begin{array}{c}1 \mathrm{M} \mathrm{LiPF}_{6}, \\
\mathrm{EC}: \mathrm{DEC}=1: 1 \\
\text { vol } \%, 10 \mathrm{wt} \% \\
\text { FEC }\end{array}$} & $\begin{array}{l}850 \mathrm{mAh} / \mathrm{g} \text { at } \\
200^{\text {th }} \mathrm{cycle} \text { at } \\
0.5 \mathrm{C}\end{array}$ & \multirow{2}{*}{$\begin{array}{l}\text { This } \\
\text { work }\end{array}$} \\
\hline & & 0.5 & & $\begin{array}{l}1125 \mathrm{mAh} / \mathrm{g} \\
\text { at } 200^{\text {th }} \mathrm{cycle} \\
\text { at } 0.5 \mathrm{C}\end{array}$ & \\
\hline $\begin{array}{l}\text { Poly (acrylic } \\
\text { acid sodium) } \\
\text { grafted } \\
\text { carboxymethyl } \\
\text { cellulose } \\
\text { NaPAA-g-CMC }\end{array}$ & $60 / 20 / 20$ & 0.45 & $\begin{array}{c}1 \mathrm{M} \mathrm{LiPF}_{6}, \\
\mathrm{EC}: \mathrm{DMC}^{2}=1: 1 \\
\text { vol } \%, 10 \mathrm{wt} \% \\
\text { FEC }\end{array}$ & $\begin{array}{c}1816 \mathrm{mAh} / \mathrm{g} \\
\text { at } 100^{\text {th }} \mathrm{cycle} \\
\text { at } 0.1 \mathrm{C}\end{array}$ & 1 \\
\hline $\begin{array}{l}\text { Poly(acrylic } \\
\text { acid) (PAA) }\end{array}$ & $43 / 15 / 42$ & - & $\begin{array}{c}1 \mathrm{M} \mathrm{LiPF}_{6} \text { in } \\
\text { EC:DEC:DMC=1: } \\
1: 1 \mathrm{vol} \%, 5 \mathrm{wt} \% \\
\text { VC }\end{array}$ & $\begin{array}{c}2000 \mathrm{mAh} / \mathrm{g} \\
\text { at } 100^{\text {th }} \mathrm{cycle} \\
\text { at } 0.5 \mathrm{C}\end{array}$ & 2 \\
\hline $\begin{array}{l}\text { Poly(acrylic } \\
\text { acid)-poly(vinyl } \\
\text { alcohol) } \\
\text { PAA-PVA }\end{array}$ & $\begin{array}{c}60 / 20 \\
\text { (PAA:PVA=9:1) } \\
/ 20\end{array}$ & - & $\begin{array}{c}1 \mathrm{M} \mathrm{LiPF}_{6} \text { in } \\
\mathrm{EC}: \mathrm{DEC}^{\mathrm{DMC}=1:} \\
1: 1 \mathrm{vol} \%, 10 \mathrm{wt} \% \\
\text { FEC }\end{array}$ & $\begin{array}{c}2283 \mathrm{mAh} / \mathrm{g} \\
\text { at } 100^{\text {th }} \mathrm{cycle} \\
\text { at } 1 \mathrm{C}\end{array}$ & 3 \\
\hline Poly(dopamine) & $80 / 10 / 10$ & 0.5 & $\begin{array}{c}1 \mathrm{M} \mathrm{LiPF}_{6}, \\
\mathrm{EC}: \mathrm{DMC}=1: 1 \\
\text { vol } \%, 10 \mathrm{wt} \% \\
\text { FEC }\end{array}$ & $\begin{array}{c}1800 \mathrm{mAh} / \mathrm{g} \\
\text { at } 100^{\text {th }} \mathrm{cycle} \\
\text { at } 0.5 \mathrm{C}\end{array}$ & 4 \\
\hline $\begin{array}{l}\text { Sodium alginate } \\
\text { (Alg) }\end{array}$ & $\begin{array}{c}\text { Si:C(3:1)/Alg } \\
=85 / 15\end{array}$ & - & $\begin{array}{c}1 \mathrm{M} \mathrm{LiPF}_{6} \\
\text { DMC:EC:DEC=1: } \\
1: 1 \text { vol\% }\end{array}$ & $\begin{array}{c}2000 \mathrm{mAh} / \mathrm{g} \\
\text { at } 100^{\text {th }} \mathrm{cycle} \\
\text { at } 1 \mathrm{C}\end{array}$ & 5 \\
\hline $\begin{array}{l}\text { Polymerized } \beta \text { - } \\
\text { cyclodextrin }\end{array}$ & $60 / 20 / 20$ & 0.6 & $\begin{array}{c}1.15 \mathrm{M} \mathrm{LiPF}_{6}, \\
\text { EC:EMC:DEC=3: } \\
5: 2 \text { vol } \%\end{array}$ & $\begin{array}{l}1500 \mathrm{mAh} / \mathrm{g} \\
\text { at } 100^{\text {th }} \mathrm{cycle} \\
\text { at } 1 \mathrm{C}\end{array}$ & 6 \\
\hline
\end{tabular}




\begin{tabular}{|c|c|c|c|c|c|}
\hline $\begin{array}{l}\text { Polyrotaxane- } \\
\text { poly(acrylic } \\
\text { acid) }\end{array}$ & $\begin{array}{c}80 / 10 / 10 \\
\text { (silicon } \\
\text { microparticles } \\
\text { were used) }\end{array}$ & 1 & $\begin{array}{c}1 \mathrm{M} \mathrm{LiPF}_{6}, \\
\mathrm{EC}: \mathrm{DEC}=1: 1 \\
\text { vol } \%, 0.5 \mathrm{wt} \% \mathrm{VC} \\
\text { and } 7.5 \mathrm{wt} \% \mathrm{FEC}\end{array}$ & $\begin{array}{c}2.43 \mathrm{mAh} / \mathrm{cm}^{2} \\
\text { at } 150^{\text {th }} \mathrm{cycle} \\
\text { at } 0.2 \mathrm{C}\end{array}$ & 7 \\
\hline $\begin{array}{l}\text { Sodium } \\
\text { carboxymethyl } \\
\text { cellulose }\end{array}$ & $80 / 8 / 12$ & 1.8 & $\begin{array}{c}1 \mathrm{M} \mathrm{LiPF}_{6} \text { in } \\
\mathrm{EC}: \mathrm{DEC}=1: 2 \\
\text { vol } \%\end{array}$ & $\begin{array}{c}1100 \mathrm{mAh} / \mathrm{g} \\
\text { at } 70^{\text {th }} \text { cycle at } \\
0.03 \mathrm{C}\end{array}$ & 8 \\
\hline $\begin{array}{l}\text { Chitosan- } \\
\text { glutaraldehyde }\end{array}$ & $60 / 20 / 20$ & - & $\begin{array}{l}1 \mathrm{M} \mathrm{LiPF}_{6} \text { in a } \\
\text { mixture of solvents }\end{array}$ & $\begin{array}{c}2130 \mathrm{mAh} / \mathrm{g} \\
\text { at } 100^{\text {th }} \mathrm{cycle} \\
\text { at } 0.1 \mathrm{C}\end{array}$ & 9 \\
\hline Galactomannans & $85 / 5 / 10$ & 0.75 & $\begin{array}{c}1 \mathrm{M} \mathrm{LiPF}_{6} \text { in } \\
\mathrm{EC}: \mathrm{EMC}=1: 1 \\
\text { vol } \%\end{array}$ & $\begin{array}{c}1000 \mathrm{mAh} / \mathrm{g} \\
\text { at } 100^{\text {th }} \mathrm{cycle} \\
\text { at } 1 \mathrm{C}\end{array}$ & 10 \\
\hline Poly(acrylamide) & $70 / 15 / 15$ & $1-1.1$ & $\begin{array}{c}1 \mathrm{M} \mathrm{LiPF}_{6} \text { in } \\
\text { EC:DEC:DMC=1: } \\
1: 1 \text { vol } \%\end{array}$ & $\begin{array}{c}2000 \mathrm{mAh} / \mathrm{g} \\
\text { at } 300^{\text {th }} \mathrm{cycle} \\
\text { at } 0.1 \mathrm{C}\end{array}$ & 11 \\
\hline $\begin{array}{l}\text { Polyvinyl } \\
\text { alcohol- } \\
\text { polyethyleneimi } \\
\text { ne } \\
\text { PVA-PEI }\end{array}$ & $\begin{array}{c}60 / 20 \\
(\mathrm{PVA}: \mathrm{PEI}=8: 2) / \\
20\end{array}$ & $1.8-2.7$ & $\begin{array}{c}1 \mathrm{M} \mathrm{LiPF}_{6} \text { in } \\
\mathrm{EC}: \mathrm{DMC}=1: 1 \\
\text { vol } \%\end{array}$ & $\begin{array}{c}1060 \mathrm{mAh} / \mathrm{g} \\
\text { at } 300^{\text {th }} \mathrm{cycle} \\
\text { at } \sim 0.2 \mathrm{C}\end{array}$ & 12 \\
\hline \multicolumn{6}{|c|}{ Organic solvent-based binder } \\
\hline PVDF & $\begin{array}{c}\mathrm{Si}: \mathrm{C}(3: 1) / \mathrm{PVDF} \\
=85 / 15\end{array}$ & $0.5-0.7$ & $\begin{array}{c}1 \mathrm{M} \mathrm{LiPF}_{6}, \\
\mathrm{EC}: \mathrm{DEC}: \mathrm{FEC}=1: 1 \\
: 0.04 \text { vol\% }\end{array}$ & $\begin{array}{c}420 \mathrm{mAh} / \mathrm{g} \text { at } \\
40^{\text {th }} \text { cycle at } \\
0.1 \mathrm{C}\end{array}$ & 13 \\
\hline $\begin{array}{l}\text { Self-healing } \\
\text { polymer } \\
\text { (Diamido } \\
\text { tetraethyltriurea) }\end{array}$ & $80 / 10 / 10$ & 1.13 & $\begin{array}{c}1 \mathrm{M} \mathrm{LiPF}_{6} \text { in } \\
\text { EC:DEC:VC:FEC } \\
=1: 1: 0.05: 0.05 \\
\text { vol } \%\end{array}$ & $\begin{array}{c}1820 \mathrm{mAh} / \mathrm{g} \\
\text { at } 140^{\text {th }} \mathrm{cycle} \\
\text { at } 0.05 \mathrm{C}\end{array}$ & 14 \\
\hline
\end{tabular}




\section{XPS}

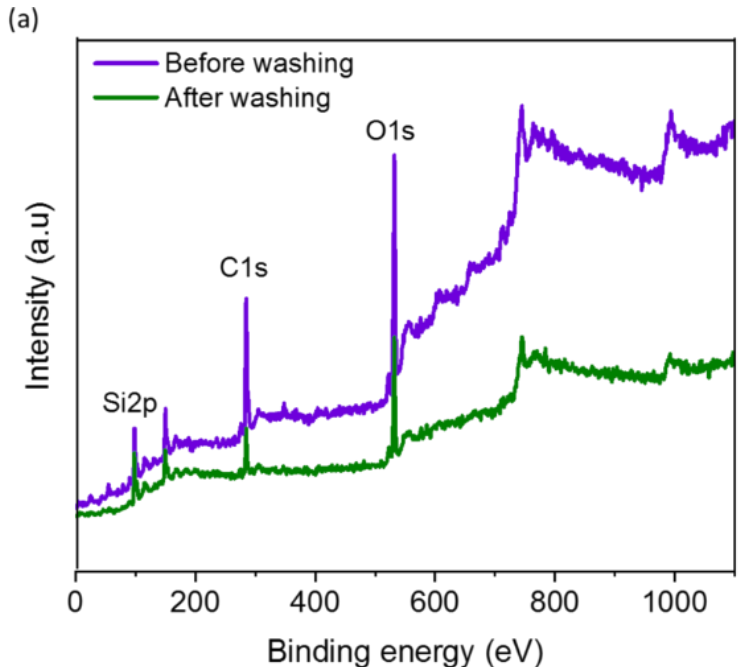

(b)

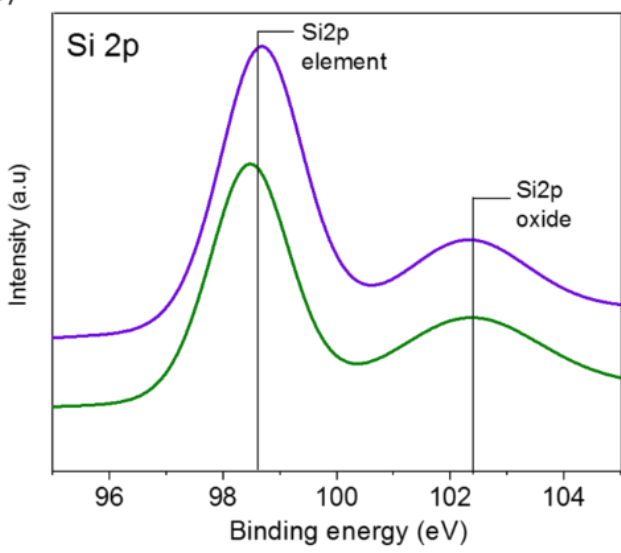

(c)

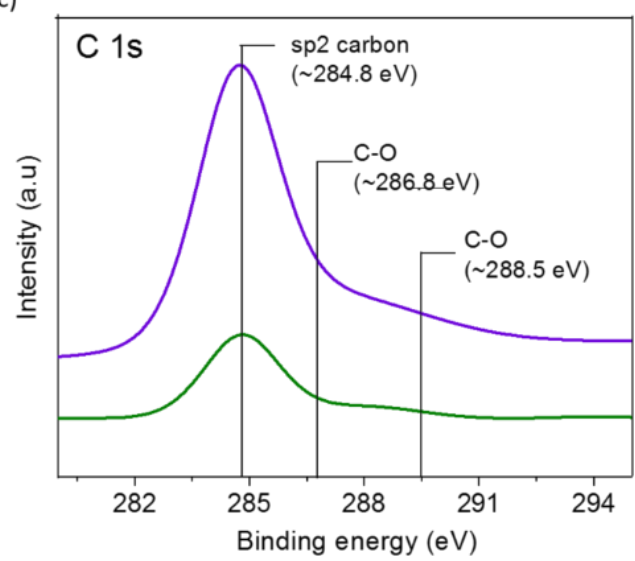

Figure S8. X-ray photoelectron spectroscopy (XPS) characterization (a) full spectra, (b) Si $2 p$ spectra, and (c) C 1s spectra of silicon nanoparticle and TA mixture before and after washing with water. More details of the experiment are given below.

A mixture of silicon nanoparticles and TA was prepared with a mass ratio of 1:1. This mixture was stirred in water for 30 minutes and then dried in a convection oven at $80^{\circ} \mathrm{C}$ to obtain a powder. Half of the powder was utilized for "before washing" analysis and half of it underwent a washing step. In the washing step, the powder was redispersed in water and the mixture was stirred for $2 \mathrm{~h}$. After this, the mixture was vacuum-filtered and washed with copious amounts of water. XPS analysis was performed on "before washing" and "after washing" samples. Even after rigorous 
washing with water, a C 1s peak from TA was observed, which implies that a substantial amount of TA remained on the surface of the silicon nanoparticle. A slight increase in C 1s peak after washing was observed which could be attributed to degradation or chemical reaction of TA with hydroxyl groups on silicon nanoparticle..$^{5-6}$ 


\section{Time of flight secondary-ion mass spectroscopy (ToF-SIMS)}

ToF-SIMS was performed on silicon electrodes before and after 50 cycles. Positive and negative high mass resolution spectra were performed using a ToF-SIMS NCS instrument, which combines a ToF.SIMS5 instrument (ION-ToF GmbH, Münster, Germany) and an in-situ scanning probe microscope (NanoScan, Switzerland) at Shared Equipment Authority from Rice University. A bunched $30 \mathrm{keV} \mathrm{Bi}^{3+}$ ions (with a measured current of $0.2 \mathrm{pA}$ ) was used as primary probe for analysis (scanned area $100 \times 100 \mu \mathrm{m}^{2}$ ) with a raster of $128 \times 128$ pixels. A charge compensation with an electron flood gun has been applied during the analysis. An adjustment of the charge effects has been operated using a surface potential of $-6 \mathrm{~V}$ and an extraction bias of $0 \mathrm{~V}$ for the positive polarity and a surface potential of $0 \mathrm{~V}$ and an extraction bias of $-20 \mathrm{~V}$ for the negative polarity. The cycle time was fixed to $90 \mu$ s (corresponding to $\mathrm{m} / \mathrm{z}=0-737$ a.m.u mass range). 

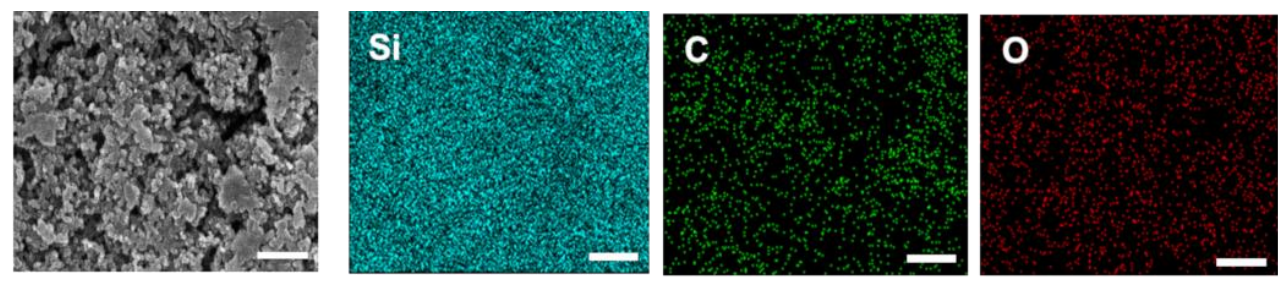

After 1 cycle
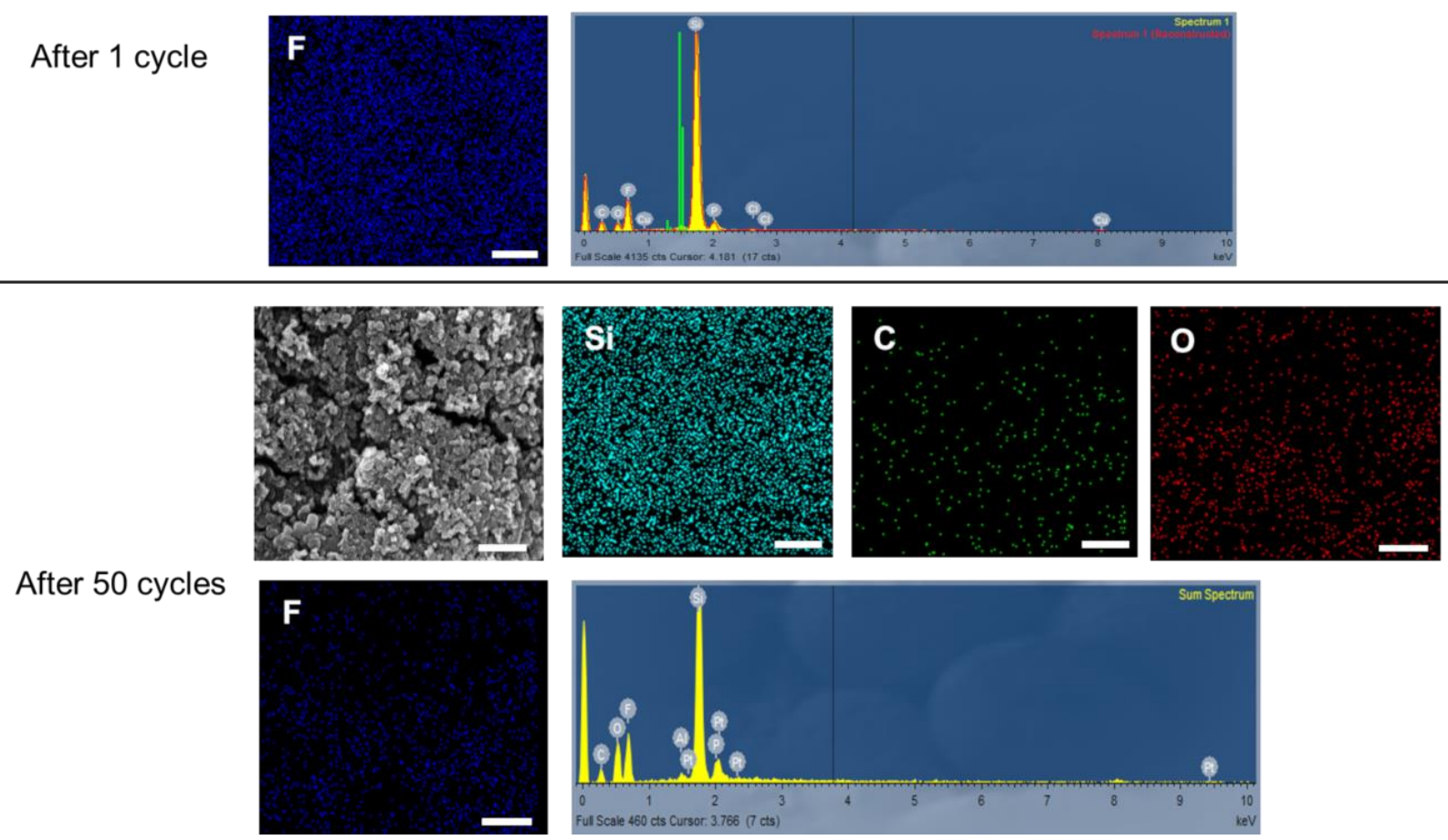

Figure S9. Energy dispersive spectroscopy (EDS) mapping of silicon electrodes after 1 cycle and after 50 cycles. The scale bar on all images is $1 \mathrm{um}$. EDS was performed on JEOL JSM SEM equipment using INCA software with an acceleration voltage of $20 \mathrm{kV}$ and a working distance of $8 \mathrm{~mm}$. 

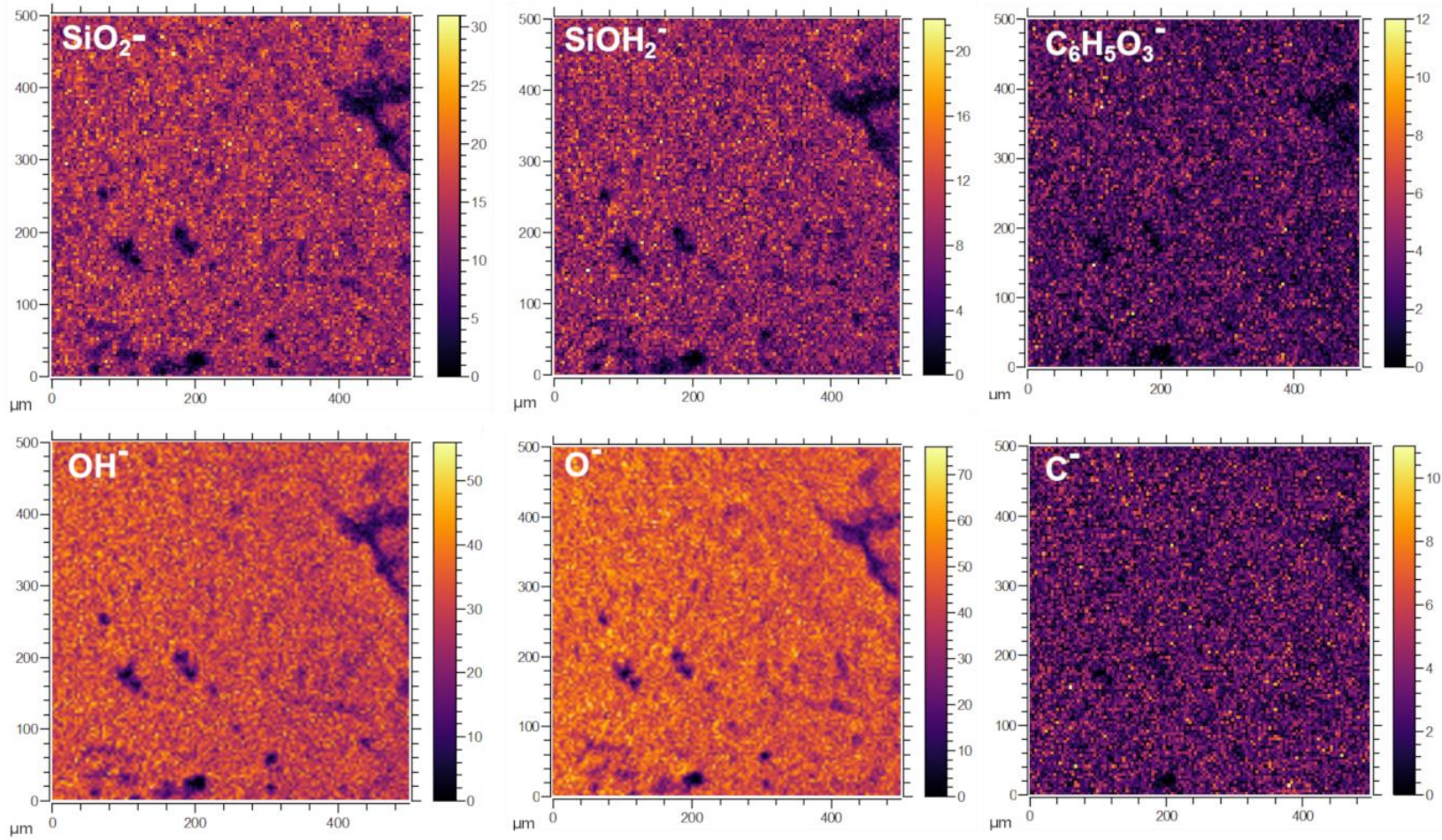

Figure S10. Time of flight secondary-ion mass spectroscopy (ToF-SIMS) surface profile images of $\mathrm{Si} / \mathrm{TA} / \mathrm{CB}=70 / 10 / 20$ electrode before cycling. $\mathrm{SiO}_{2}{ }^{-}, \mathrm{SiOH}_{2}{ }^{-}$were representative of $\mathrm{Si}$ nanoparticles, $\mathrm{C}_{6} \mathrm{H}_{5} \mathrm{O}_{3}{ }^{-}$was representative of TA and $\mathrm{C}^{-}$was representative of Super $\mathrm{P}$ carbon black $(\mathrm{CB})$. Images of $\mathrm{O}^{-}$and $\mathrm{OH}^{-}$are also shown which are representative of both $\mathrm{Si}$ and TA. The scale on both axes is in $\mu \mathrm{m}$. 

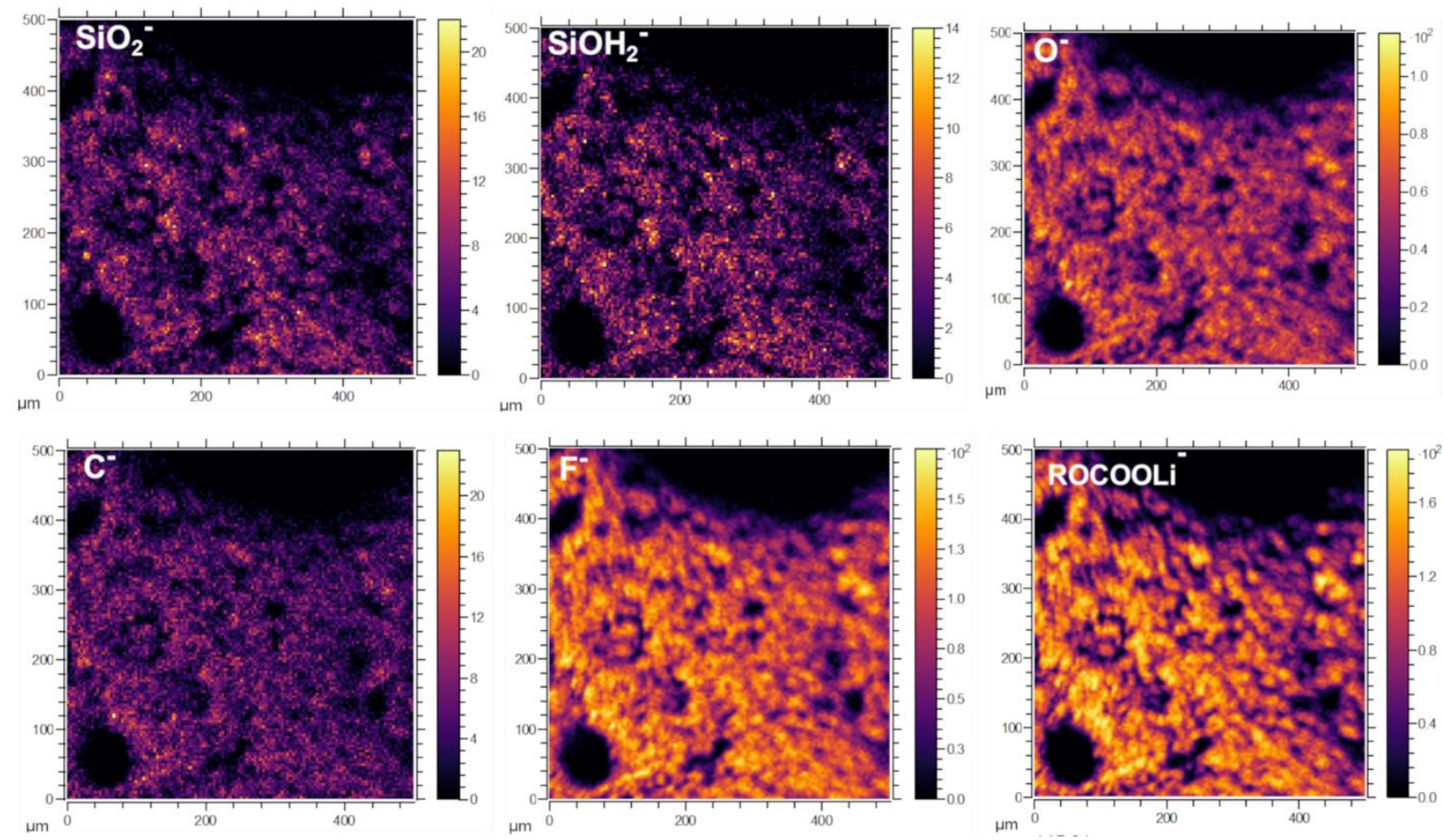

Figure S11. Time of flight secondary-ion mass spectroscopy (ToF-SIMS) surface profile images of $\mathrm{Si} / \mathrm{TA} / \mathrm{CB}=70 / 10 / 20$ electrode after 50 cycles. $\mathrm{SiO}_{2}^{-}, \mathrm{SiOH}_{2}^{-}$were representative of $\mathrm{Si}$ nanoparticles. No image representing TA is shown here because TA was buried under the layer of SEI. Images of $\mathrm{O}^{-}$and $\mathrm{OH}^{-}$are shown which might be representative of $\mathrm{Si}$, TA, and compounds of SEI. RO-COOLi, $\mathrm{F}^{-}$are representative of SEI seen in the surface profiling image of electrode after cycling. The scale on both axes is in $\mu \mathrm{m}$. 


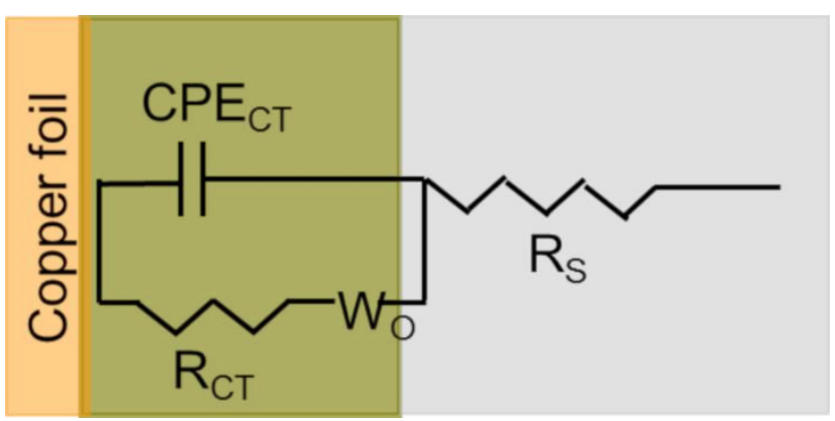

Figure S12. Equivalent circuit used to model before cycling EIS data of $\mathrm{Si} / \mathrm{TA} / \mathrm{CB}=70 / 10 / 20$ electrode (Figure 7a).

(a)

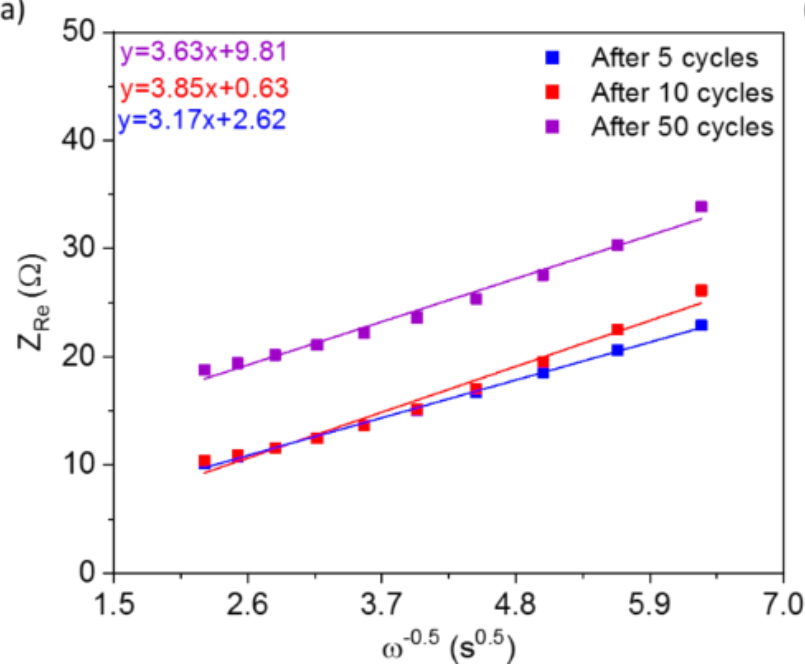

(b)

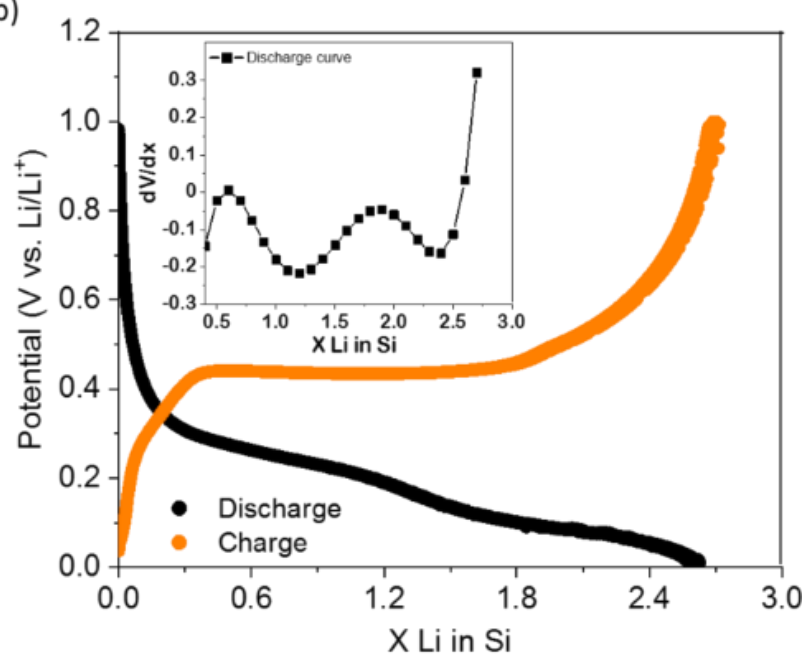

Figure S13. (a) Plot of real impedance $\left(Z_{R e}\right)$ vs. $\omega^{-0.5}$. This graph is plotted using the electrochemical impedance spectroscopy (EIS) data (Figure 7a). The slope values $\left(\sigma, \Omega s^{-0.5}\right)$ are used to calculate solid-state diffusion coefficient of $\mathrm{Li}^{+}$ions using Eqn 2 (given below). (b) Plot of potential $(V) v s . X$ for the fifth cycle at $0.5 \mathrm{C}$. Here $X$ is the amount of Li ions in silicon. Inset shows a plot of $d V / d x v s . X$. More details on the plot is given below. 
Table S2. The results of fitting an equivalent circuit to the EIS data.

\begin{tabular}{lcccccccc}
\hline & $R_{O}$ & $R_{S E I}$ & $C P E_{S E I}$ & $R_{C T}$ & $C P E_{C T}$ & & $\sigma$ & Solid-state $\mathrm{D}_{\mathrm{Li}^{+}}$ \\
& $(\Omega)$ & $(\Omega)$ & $\left(\mathrm{x} 10^{-5} \mu \mathrm{F}\right)$ & $(\Omega)$ & $\left(\mathrm{x} 10^{-4} \mu \mathrm{F}\right)$ & $\chi^{2}$ & $(\Omega / \mathrm{s})$ & $\left(\mathrm{x} 10^{-12} \mathrm{~cm}^{2} / \mathrm{s}\right)$ \\
\hline $\begin{array}{l}\text { Before } \\
\text { cycling }\end{array}$ & 1.81 & - & - & 66.1 & 5.55 & 0.001 & - & - \\
& & & & & & & & \\
\hline $\begin{array}{l}\text { After 5 } \\
\text { cycles }\end{array}$ & 1.05 & 1.71 & 0.50 & 3.55 & 5.88 & 0.005 & 3.21 & 6.44 \\
\hline $\begin{array}{l}\text { After 10 } \\
\text { cycles }\end{array}$ & 1.12 & 2.68 & 0.47 & 2.76 & 8.98 & 0.004 & 4.35 & 8.99 \\
\hline $\begin{array}{l}\text { After 50 } \\
\text { cycles }\end{array}$ & 1.71 & 7.53 & 1.06 & 1.47 & 0.74 & 0.005 & 4.03 & 8.80 \\
\hline
\end{tabular}

Equivalent circuits as shown in Figure S12 and 7b were fit to the Nyquist data (Figure 7a), before and after cycling, respectively. The fit values are shown in the above table (Table S2). $\chi^{2}$ was used as a criterion to determine how well the model fit the experimental data, and since the $\chi^{2}$ values were in the range of $10^{-2}$, the model represented a good fit. The following equations ${ }^{15-16}$ were used to calculate the diffusion coefficient of $\mathrm{Li}^{+}$ions in the silicon anode and calculation details are provided further.

$$
\begin{aligned}
& Z_{R e}=R_{O}+R_{C T}+\sigma \omega^{-0.5} \\
& D_{L i^{+}}=\frac{1}{1}\left[\left(\frac{V_{M}}{F S \sigma}\right)\left(\frac{d V}{d X}\right)\right]^{2}
\end{aligned}
$$


where, $D_{L i+}$ is the diffusion coefficient $\left(\mathrm{cm}^{2} / \mathrm{s}\right), \omega$ is the radial frequency $\left(\mathrm{s}^{-1}\right), Z_{R e}$ is the real impedance, $R_{O}$ is ohmic resistance, and $R_{C T}$ is charge transfer resistance, $V_{M}$ is the molar volume of silicon, $F$ is Faraday's constant $(96485 \mathrm{C} / \mathrm{mol}), S$ is the surface area of electrode (for simplicity, the geometric area of the electrode in $\mathrm{cm}^{2}\left(2.01 \mathrm{~cm}^{2}\right)$ is used), $\sigma$ is a parameter calculated from the slope of the plot of real impedance $\left(Z_{R e}\right) v s . \omega^{-0.5}$ (Figure S13a and Eqn 1), and $d V / d X$ is the slope of electrode potential $(V) v s$. plot $\mathrm{Li}$ ions in $\operatorname{Si}(X)$. The plot of $V v s . X$ for the sixth cycle and $d V / d X$ vs. $X$ is as shown in Figure S13b and inset, respectively. Here, $X$ is number of $\mathrm{Li}^{+}$ions in silicon. $d V / d x$ is calculated from the plot of $V v s . X$ by fitting a higher order degree polynomial and then differentiating it with respect to $X$. This $d V / d X$ and sigma is then used to calculate diffusion coefficient using Eqn 2. Figure S13b can be recreated for different cycling number as required. These calculations were done for before cycling, after 5 cycles, 10 cycles and 50 cycles and highest diffusion coefficient value in each case was recorded in the Table S2. 


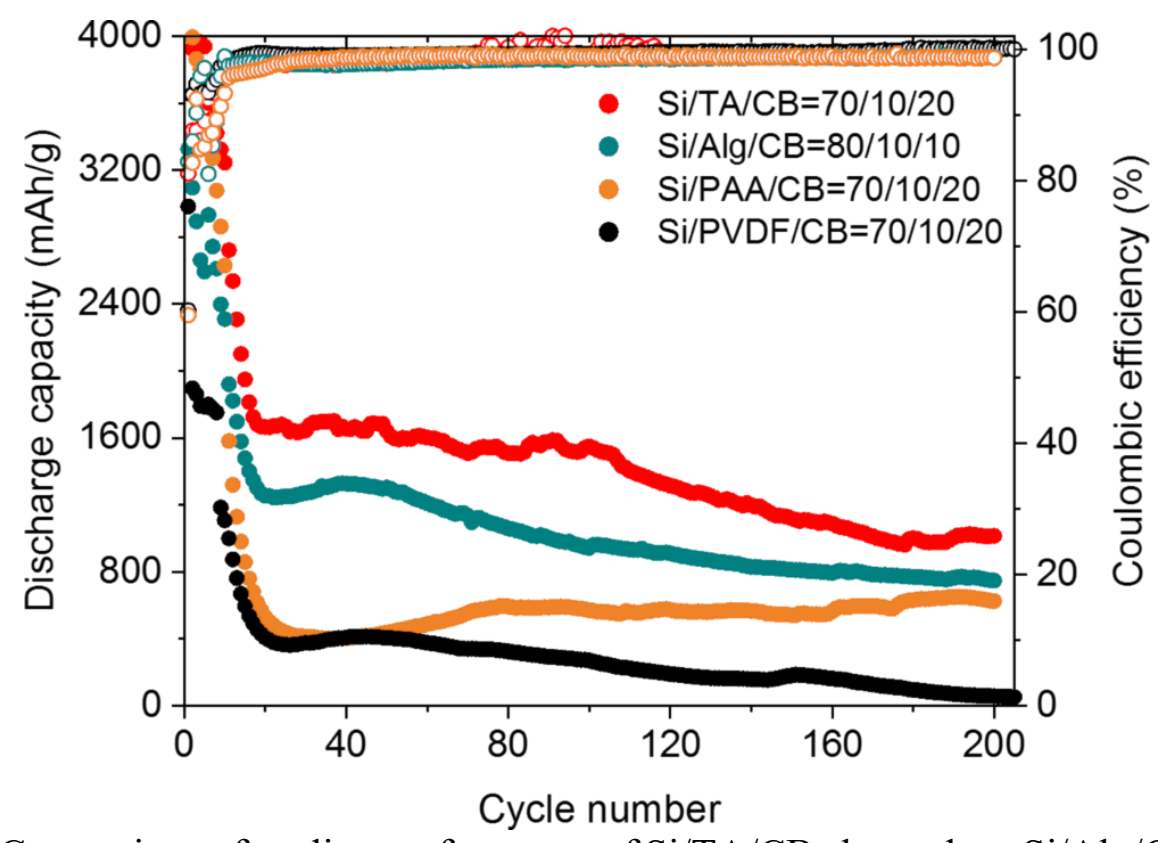

Figure S14. Comparison of cycling performance of $\mathrm{Si} / \mathrm{TA} / \mathrm{CB}$ electrode to $\mathrm{Si} / \mathrm{Alg} / \mathrm{CB}, \mathrm{Si} / \mathrm{PAA} / \mathrm{CB}$, and $\mathrm{Si} / \mathrm{PVDF} / \mathrm{CB}$ electrode. Here, similar active material loading, same battery assembly and cycling conditions were used to make a direct comparison. 
Table S3. Comparison of different binders and the millimoles of hydroxyl (-OH) and carboxyl ($\mathrm{COOH}$ ) functional groups per gram of the binder. For polymers, the molecular weight is that of the repeat unit.

\begin{tabular}{l|lccccc}
\hline \multicolumn{1}{c}{ Type } & $\begin{array}{l}\text { Molecular } \\
\text { weight } \\
(\mathrm{g} / \mathrm{mol})\end{array}$ & $\begin{array}{l}\text { No. of } \\
\mathrm{OH} / \mathrm{unit}\end{array}$ & $\begin{array}{l}\text { Millimoles } \\
\text { of OH/g }\end{array}$ & $\begin{array}{l}\text { No. of } \\
\mathrm{COOH} / \\
\text { unit }\end{array}$ & $\begin{array}{l}\text { Millimoles } \\
\text { of } \\
\mathrm{COOH} / \mathrm{g}\end{array}$ \\
$\begin{array}{l}\text { Low molecular } \\
\text { weight } \\
\text { branched } \\
\text { molecule }\end{array}$ & Tannic acid & 1686 & 25 & 14.8 & - & - \\
\hline & $\begin{array}{l}\text { Polyacrylic } \\
\text { acid }\end{array}$ & $72^{\mathrm{a}}$ & - & - & 1 & 13.8 \\
\cline { 2 - 8 } $\begin{array}{l}\text { Long chain } \\
\text { linear polymers }\end{array}$ & $\begin{array}{l}\text { Sodium salt of } \\
\text { alginic acid }\end{array}$ & $219^{\mathrm{a}}$ & 4 & 18.3 & 2 & 9.13 \\
\cline { 2 - 8 } & $\begin{array}{l}\text { Polyvinylidene } \\
\text { fluoride }\end{array}$ & $64^{\mathrm{a}}$ & - & - & - & - \\
\cline { 2 - 8 } & Polydopamine & $150^{\mathrm{a}}$ & 2 & 13.3 & - & - \\
\hline
\end{tabular}

${ }^{\mathrm{a}}$ Molecular weight per polymer repeat unit. 


\section{References}

1. Wei, L.; Chen, C.; Hou, Z.; Wei, H., Poly (acrylic acid sodium) Grafted Carboxymethyl Cellulose as a High Performance Polymer Binder for Silicon Anode in Lithium Ion Batteries. Sci. Rep. 2016, 6, 19583.

2. Magasinski, A.; Zdyrko, B.; Kovalenko, I.; Hertzberg, B.; Burtovyy, R.; Huebner, C. F.; Fuller, T. F.; Luzinov, I.; Yushin, G., Toward Efficient Binders for Li-Ion Battery Si-Based Anodes: Polyacrylic Acid. ACS Appl. Mater. Interfaces 2010, 2 (11), 3004-10.

3. He, J.; Zhang, L., Polyvinyl Alcohol Grafted Poly (acrylic acid) as Water-Soluble Binder with Enhanced Adhesion Capability and Electrochemical Performances for Si Anode. J. Alloys Compd. 2018, 763, 228-240.

4. Bie, Y.; Yang, J.; Liu, X.; Wang, J.; Nuli, Y.; Lu, W., Polydopamine Wrapping Silicon Cross-linked with Polyacrylic Acid as High-Performance Anode for Lithium-Ion Batteries. ACS Appl. Mater. Interfaces 2016, 8 (5), 2899-904.

5. Kovalenko, I.; Zdyrko, B.; Magasinski, A.; Hertzberg, B.; Milicev, Z.; Burtovyy, R.; Luzinov, I.; Yushin, G., A Major Constituent of Brown Algae for Use in Silicon Anodes. Science 2011, 7 (6052), 75-79.

6. Jeong, Y. K.; Kwon, T. W.; Lee, I.; Kim, T. S.; Coskun, A.; Choi, J. W., Hyperbranched Beta-Cyclodextrin Polymer as an Effective Multidimensional Binder for Silicon Anodes in Lithium Rechargeable Batteries. Nano Lett. 2014, 14 (2), 864-70. 
7. Choi, S.; Tae-woo Kwon, T.-W.; Coskun, A.; Choi, J. W., Highly Elastic Binders Integrating Polyrotaxanes for Silicon Microparticles Anode in Li Ion Batteries. Science 2017, 357 (6348), 279-283.

8. Li, J.; Lewis, R. B.; Dahn, J. R., Sodium Carboxymethyl Cellulose A Potential Binder for Silicon Electrodes. Electrochem. Solid-State Lett. 2007, 10 (2), A17- A20.

9. Chen, C.; Lee, S. H.; Cho, M.; Kim, J.; Lee, Y., Cross-Linked Chitosan as an Efficient Binder for Si Anode of Li-ion Batteries. ACS Appl. Mater. Interfaces 2016, 8 (4), 2658-65.

10. Dufficy, M. K.; Khan, S. A.; Fedkiw, P. S., Galactomannan Binding Agents for Silicon Anodes in Li-Ion Batteries. J. Mater. Chem. A 2015, 3 (22), 12023-12030.

11. Zhu, X.; Zhang, F.; Zhang, L.; Zhang, L.; Song, Y.; Jiang, T.; Sayed, S.; Lu, C.; Wang, X.; Sun, J.; Liu, Z., A Highly Stretchable Cross-Linked Polyacrylamide Hydrogel as an Effective Binder for Silicon and Sulfur Electrodes toward Durable Lithium-Ion Storage. Adv. Func. Mater. 2018, 28 (11), 1705015-27.

12. Liu, Z.; Han, S.; Xu, C.; Luo, Y.; Peng, N.; Qin, C.; Zhou, M.; Wang, W.; Chen, L.; Okada, S., In situ Crosslinked PVA-PEI Polymer Binder for Long-Cycle Silicon anodes in Li-Ion Batteries. RSC Adv. 2016, 6 (72), 68371-68378.

13. Chen, L.; Xie, X.; Xie, J.; Wang, K.; Yang, J., Binder Effect on Cycling Performance of Silicon/Carbon Composite Anodes for Lithium Ion Batteries. J. Appl. Electrochem. 2006, 36 (10), 1099-1104. 
14. Wang, C.; Wu, H.; Chen, Z.; McDowell, M. T.; Cui, Y.; Bao, Z., Self-healing Chemistry Enables the Stable Operation of Silicon Microparticle Anodes for High-Energy Lithium-Ion Batteries. Nat. Chem. 2013, 5 (12), 1042-8.

15. Ding, N.; Xu, J.; Yao, Y. X.; Wegner, G.; Fang, X.; Chen, C. H.; Lieberwirth, I., Determination of the Diffusion Coefficient of Lithium Ions in Nano-Si. Solid State Ionics 2009, $180(2-3), 222-225$.

16. Xie, J.; Imanishi, N.; Zhang, T.; Hirano, A.; Takeda, Y.; Yamamoto, O., Li-Ion Diffusion in Amorphous Si Films Prepared by RF Magnetron Sputtering: A Comparison of Using Liquid and Polymer Electrolytes. Mater. Chem. Phys. 2010, 120 (2-3), 421-425. 